\title{
ANT FAUNA ASSOCIATED WITH AREAS UNDER THE DIRECT IMPACT OF SMALL HYDROPOWER PLANTS IN THE STATE OF PARANÁ, BRAZIL
} MIRMECOFAUNA ASSOCIADA ÀS ÁREAS DE INFLUÊNCIA DIRETA DE PEQUENAS CENTRAIS HIDRELÉTRICAS NO ESTADO DO PARANÁ, BRASIL

\section{Junir Antonio Lutinski}

Ph.D. in Animal Biodiversity. Professor of the Graduate Program in Health Science, Community University of Chapecó Region (Unochapeco).

\section{Cristiano Ilha}

Ms. in Biology. Biologist of the Regional Health Management of Santa Catarina state (GERSA).

\section{Cladis Juliana Lutinski}

Ms. in Biology. Biologist of the Federal University of Fronteira Sul (UFFS).

\section{Leandro Baucke}

Biologist of Impacto Ambiental Advisory.

\section{Milton de Filtro}

Biologist of Impacto Ambiental Advisory.

\section{Maria Assunta Busato}

Ph.D. in Biology. Professor of the Post-Graduate Program in Health Science, Unochapeco.

\section{Flávio Roberto Mello Garcia}

Ph.D. in Biology. Professor of the Post-Graduate Program in Phytosanitary at the Federal University of Pelotas (UFPel).

\section{Corresponding address:}

Junir Antonio Lutinski - Rua BeijaFlor, 254 E-Efapi -89809-760Chapecó (SC), Brasil E-mail: junir@unochapeco.edu.br

Received: 10/27/2016

Accepted: 09/11/2017

\section{ABSTRACT}

Ants can be important tools to assess the conditions of a given environment, as well as to monitor restoration of degraded areas. This study evaluated the richness and abundance of ant assemblages associated with areas directly impacted by the construction of small hydropower plants in the State of Paraná. To survey the ant fauna, samples were collected in September 2014 and January 2015 using pitfall and malaise traps. The association of the ant fauna composition with fragments and seasonality was analyzed by detrended correspondence. Fifty-eight species of ants were registered. The subfamily Myrmicine and the genus Camponotus were the most abundant ( $S=25$, $S=10$, respectively). The removal of vegetation and formation of lakes in the directly affected area cause impacts that can be monitored based on the results of this study.

Keywords: ants; environment; environmental health; forests.

\section{RESUMO}

Formigas são importantes ferramentas para avaliar as condições de um determinado ambiente, bem como o acompanhamento da recuperação de áreas degradadas. O objetivo deste trabalho foi avaliar a riqueza e a abundância das assembleias de formigas associadas às Áreas de Influência Direta (AID) pela construção de pequenas Centrais Hidrelétricas (PCH) no estado do Paraná. Foram realizadas duas campanhas sazonais de amostragem, setembro de 2014 e janeiro de 2015. A amostragem foi realizada com armadilhas pitfall e Malaise. A relação da composição da mirmecofauna com os fragmentos e a sazonalidade foi avaliada a partir de uma análise de correspondência destendenciada. Foram registradas 58 espécies de formigas. A subfamília Mymicinae e o gênero Camponotus foram os mais ricos ( $S=25 ; S=10$, respectivamente). A supressão da vegetação e a formação dos lagos na Área Diretamente afetada (ADA) causam impactos que poderão ser monitorados com base nos resultados deste estudo.

Palavras-chave: formigas; ambiente; saúde ambiental; florestas. 


\section{INTRODUCTION}

Human activities and exploitation of natural resources pose threats to biodiversity conservation (DIAMOND, 2012). The transformation of natural environments into areas intended for human undertakings is the main cause of ecosystem fragmentation and a risk to the conservation of the diversity of organisms (GALINDO-LEAL; CÂMARA, 2003). There is a growing concern for environmental sustainability and the environmental impacts of the current energy matrix, based on the burning of fossil fuels (LUTINSKI et al., 2017). In this context, Small Hydropower Plants (SHP) represent an alternative of lower impact compared to large hydropower plants (KLIEMANN; DELARIVA, 2015).

During the construction of a SHP, the known impacts are related to the removal of vegetation in the directly affected area (DAA), construction of roads and power transmission networks, land compaction machines and, finally, the formation of the lake. During and especially after its implementation, the SHP can affect climate, temperature and local humidity and, consequently, the communities of organisms present in the areas under the direct impact (ADI) (BARBOSA FILHO, 2013; KLIEMANN; DELARIVA, 2015). However, little is known about the impact on the richness and abundance of invertebrate organisms living in these environments.

The study of organisms has been one of the techniques used to evaluate changes in the environment. Insects are ecological indicators to assess the impact that may occur in a given environment (LUTINSKI et al., 2013a). Formicidae is one of the most diverse insect taxa (HÖLLDOBLER; WILSON, 1990) and has wide distribution, high richness and abundance in terrestrial ecosystems (ALONSO; AGOSTI, 2000). For Jamison et al. (2016), ants are biodiversity indicators, as they are easy to collect, reach a wide range of herbivore hosts and indicate the conditions of plant communities. Ants are recognized as biological indicators, a tool to assess environmental conditions and monitoring degraded areas and the regeneration of forest areas (ILHA et al., 2009; ARENAS et al., 2015). These insects fulfill this role because they have a wide geographical distribution, are locally abundant, functionally important at all trophic levels and susceptible to ecological changes (HÖLLDOBLER; WILSON, 1990).

In the state of Paraná, the pioneer entomofauna surveys were performed by Sakagami et al. (1967) and Gonçalves and Melo (2005). Such studies focused on the impact of deforestation, habitat fragmentation, introduction of exotic species, irrational agricultural practices and the reduction of native insect populations (LUTINSKI et al., 2017). Although the state of Paraná has stood out for being the first in southern Brazil demanding the investigation of invertebrate fauna in Environmental Impact Study/Environmental Impact Report (EIS/EIR), which is adding significant knowledge on the occurrence and distribution of entomofauna, the state still lacks studies on the ant fauna.

Considering that the state of Paraná has important production of energy from SHP (KLIEMANN; DELARIVA, 2015), this study aimed to:

- Evaluate the richness and abundance of ants assemblages associated with areas under the direct impact (ADI) from the construction of small hydropower plants, in the northeast region of the state of Paraná;

- Analyze the association between occurrences of ant species and the environments sampled and the sampling periods;

- Produce information about the existing ant fauna for monitoring in the period after the implementation of SHP.

\section{MATERIAL AND METHODS}

\section{Study area}

The study was developed in an ecotone, a transition region between the Atlantic Forest and Cerrado, along the banks of the Fortaleza River, municipalities of Piraí do Sul, Tibagi and Ventania, in the northeastern region of the state of Paraná (Figure 1).
Five sampling sites were established in the river basin, where three SHP are projected to be implemented. The sites, located in the ADI of the undertakings, are composed of small forest fragments, located by the river: 
- Site 1 (2425'36" W; 5013'54" S): 2 ha area, well-preserved environment, with well-formed litter and covered by dense vegetation. It is surrounded by crops of corn and soybeans, houses and pastures;

- Site 2 (2425'28" W; 5012'58" S): 6 ha area, forest fragment at advanced state of regeneration, with a wellformed litter and a dense understory. It is amidst crops, pastures and eucalyptus (Eucalyptus sp.) reforestation;

- Site 3 (2425'55" W; 50¹1'22" S): 2.5 ha area, amidst a pasture area with almost no litter and heavy trampling by cattle;

\section{Sampling}

To survey the ant fauna in forest fragments, two seasonal samplings were performed, one on September 1618, 2014 (winter) and another on January 13-15, 2015 (summer). Soil pitfall traps were used, which consisted of
- Site 4 (2425'34" W; 5011'28" S): 4.5 ha area, at an intermediate stage of regeneration and is surrounded by eucalypt plantations, shrub and grasses. It does not have well-defined litter. It is also crossed by several roads and tracks used for silvicultural activities, logging and sand mining;

- Site 5 (2425'17" W; 5010’37" S): 4 ha area, presents the best preservation conditions. It is at an advanced stage of ecological succession, has a wellformed litter and dense vegetation. Traces of human action in this fragment are minimal.

$500 \mathrm{~mL}$ plastic cups $(7.5 \mathrm{~cm}$ diameter $\times 11.5 \mathrm{~cm}$ height), buried to the rim. Inside each trap, we added $150 \mathrm{~mL}$ water with a drop of detergent to break the surface tension of water. Ten pitfall traps were set at each site, in each

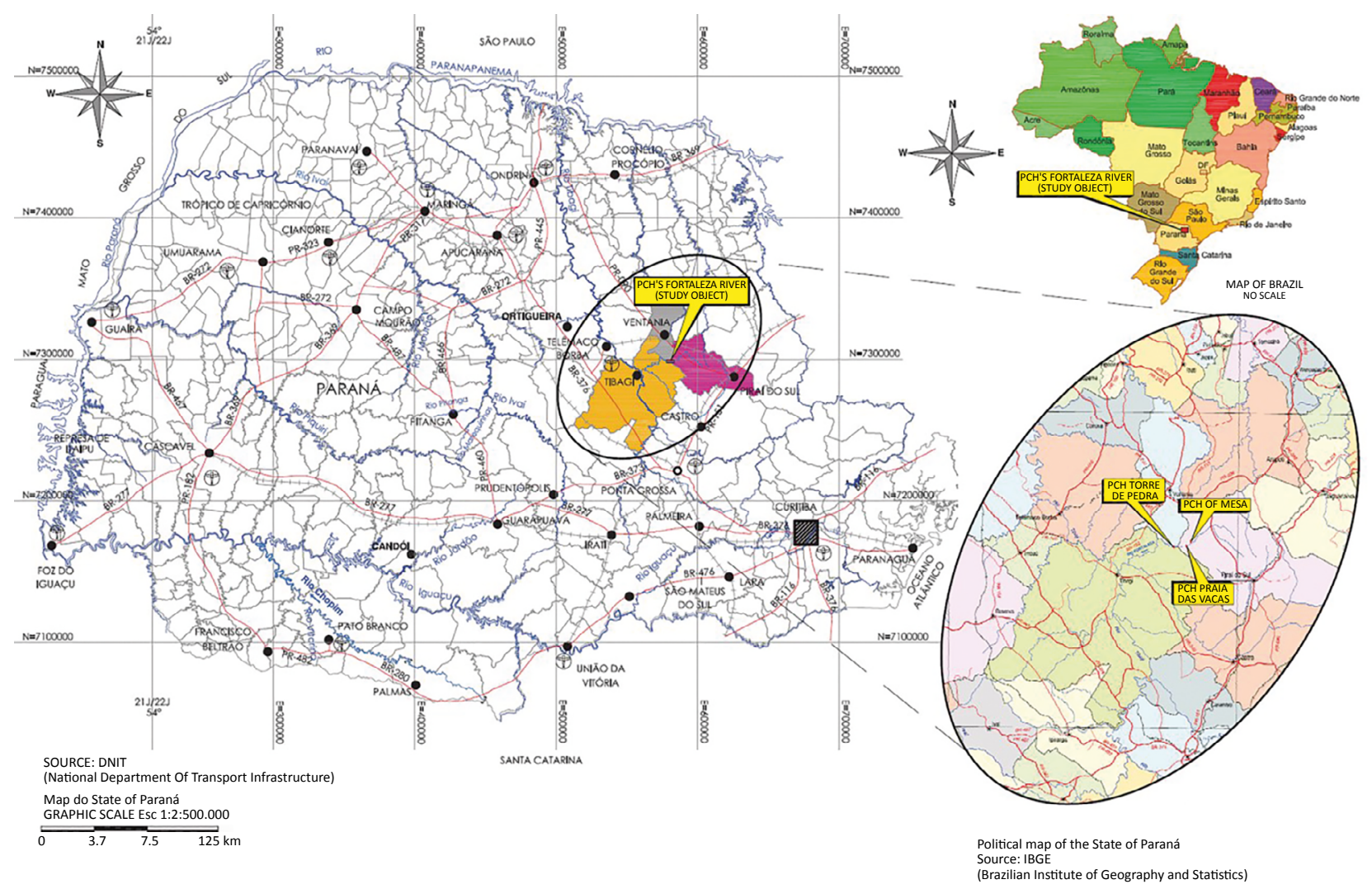

Figure 1 - Geographic location of three Small Hydroelectric Power Plants in Rio Fortaleza, Piraí do Sul, Tibagi and Ventania municipalities, Paraná, Brazil. 
sampling. They were installed at an approximately central point, on a line transect, spaced apart by 10 meters (LUTINSKI et al., 2013b) and remained open for 48 hours.

Malaise traps were also used, one trap per site, in each sampling, totaling two samples for each site. The installation was carried out in transition environments between forest fragments and crops or grazing areas. The trap was made in white, with black septa and had a specific collector glass to $70 \%$ alcohol, used for fixing

\section{Data analysis}

Species richness was defined as the number of species of ants occurring in each sample. Abundance was determined based on the relative frequency (number of records of a given species in each trap) and not based on the number of sampled individuals (LUTINSKI et al., 2014). The percentage relative frequency was calculated for each species by the equation $\mathrm{F}(\%)=\mathrm{Fi} \times 100 / \mathrm{Ft}$, where $\mathrm{Fi}$ is the number of occurrences of a given species in a given site and $\mathrm{Ft}$ is the total number of occurrences for this site.

The evaluation of diversity (richness and abundance) was performed using the Shannon-Weaver diversity index. This index allows estimating the local species diversity. The evenness is the contribution of each taxon in the community and was defined by the Pielou index (MAGURRAN, 1988). Both analyses were obtained using the software PAST (HAMMER et al., 2001).

In order to assess sampling sufficiency (number of taxa according to the sampling sites), we constructed a species accumulation curve for the assemblage of ants in each site. We also obtained a richness estimate for insects. The sampled specimens were collected at the end of 48 hours of trap exposure.

All specimens were transferred to vials containing $70 \%$ alcohol and taken to the laboratory of Entomology at the Community University of Chapecó Region (Unochapecó), where they were sorted and organized for identification according to the following literature: Fernández (2003) and Baccaro et al. (2015). The classification follows Bolton (2003).

each site and compared it with the respective observed richness. For this, we used the nonparametric Chao 1 estimator and estimates were generated by the software EstimateS 8.0 (COLWELL, 2006). The Chao 1 estimator essentially uses information about the species occurring in a sample (unicates) and those that occur in two samples (duplicates) (CHAO, 1987).

All data were tested for homoscedasticity (Levene's test) and normality (Kolmogorov-Smirnov test). Before the multivariate analysis, biotic and abiotic data were standardized and the values were transformed (rootsquare transformation) to minimize the effect of outliers. It was used Detrended correspondence analysis (DCA) to establish the relationship of the ant fauna composition with the sampling sites and seasonality. Axes with eigenvalues greater than 0.20 were retained for interpretation. To investigate the effects of the environment and seasons on the species composition, the scores of the first two significant axes of the DCA were tested using analysis of variance (ANOVA). For this analysis, we used the STATISTICA 8.0 software (STATSOFT, Inc., 2007).

\section{RESULTS}

In the ADI, 58 species of ants were recorded; 57 were caught in pitfall traps and eight in Malaise traps, only Pachycondyla villosa (Fabricius, 1804) was exclusive to this method of capture. The subfamily Mymicinae was the most species-rich $(S=25)$, followed by Formicinae $(S=13)$ and Ponerinae $(S=7)$. The genus Camponotus was the most representative, with 10 species, followed by Pheidole ( $\mathrm{S}=6)$, Linepithema, Pachycondyla, Pseudomyrmex and Solenopsis $(S=4)$. The highest richness was obtained in the winter ( $S=45)$, followed by sum$\operatorname{mer}(S=33)$ (Table 1$)$.
As for the frequencies in the samples, Gnamptogenys striatula Mayr, 1884 and Pheidole sp. 4 were the most frequent species in site 1 . In site 2 , the frequency of Pheidole sp. 1 and Pheidole sp. 4 were the highest. In site 3, Pheidole sp. 1 and Pheidole sp. 6 and, in site 4, Solenopsis saevissima (F. Smith, 1855) and Pachycondyla striata (F. Smith, 1858) were the most frequent. Site 5 had Pheidole sp. 4 and Linepithema sp. 2 as the most frequent (Table 1). With the exception of site $4\left(S^{\prime}=11\right)$, the other sites presented similar richness (Site 1: $S=24$; Site 2: $S=$ 25; Site 3: $S=25$, and Site $5: S=26$ ). The higher diversity 
Table 1 - Relative frequency (\%) of occurrence of ant species in samples from five sites under the direct impact from small hydropower plants in the Fortaleza River, municipalities of Piraí do Sul, Tibagi and Ventania, state of Paraná, Brazil. September 2014 and January 2015.

\begin{tabular}{|c|c|c|c|c|c|}
\hline \multirow{2}{*}{ Táxon } & \multicolumn{5}{|c|}{ Sites } \\
\hline & 1 & 2 & 3 & 4 & 5 \\
\hline \multicolumn{6}{|l|}{ Subfamily Dolichoderinae } \\
\hline \multicolumn{6}{|l|}{ Tribe Dolichoderini } \\
\hline Dorymyrmex brunneus (Forel, 1908) & 1.6 & 2.1 & & 4.8 & 2.0 \\
\hline Dorymyrmex pyramicus (Roger, 1863) & & & 4.7 & & 2.0 \\
\hline Linepithema humile (Mayr, 1868) & & & 4.7 & & 3.9 \\
\hline Linepithema sp. 1 & 9.4 & 8.5 & 4.7 & 4.8 & 3.9 \\
\hline Linepithema sp. 2 & 3.1 & 2.1 & & & 9.8 \\
\hline Linepithema sp. 3 & & 4.3 & & & 3.9 \\
\hline
\end{tabular}

Subfamily Ectatomminae

Tribe Ectatommini

\begin{tabular}{|l|l|l|l|}
\hline Gnamptogenys striatula Mayr, 1884 & 14.1 & 8.5 & 4.7 \\
\hline Gnamptogenys sp. & & 4.3 & 4.7 \\
\hline
\end{tabular}

Subfamily Formicinae

Tribe Camponotini

Camponotus atriceps (F. Smith, 1858)

2.1

4.8

Camponotus diversipalpus Santschi, 1922

Camponotus melanoticus Emery, 1894

3.1

\begin{tabular}{|l|r|}
\hline 4.7 & 5.9 \\
\hline
\end{tabular}

Camponotus mus Roger, 1863

Camponotus rufipes (Fabricius, 1775)

3.1

4.7

Camponotus sp. 1

3.1

2.3

14.3

3.9

Camponotus sp. 2

1.6

2.1

2.3

2.1

Camponotus sp. 3

2.3

2.3

Camponotus sp. 4

Camponotus sp. 5

\section{3}

Tribe Plagiolepidini

Brachymyrmex coactus Mayr, 1887

2.1

Brachymyrmex sp.

4.3

Paratrechina longicornis (Latreille, 1802)

1.6

Subfamily Heteroponerinae

Tribe Heteroponerini

Heteroponera flava Kempf, 1962

1.6

Subfamily Myrmicinae

Tribe Attini

Acromyrmex niger (F. Smith, 1858)

Acromyrmex rugosus (F. Smith, 1858)

Acromyrmex subterraneus (Forel, 1893)

Cyphomyrmex strigatus Mayr, 1887

Mycocepurus goeldii (Forel, 1893)
1.6

2.1

2.0

4.7

4.3

2.3

2.3

4.7

4.8

5.9

\begin{tabular}{l|l}
2.1 & 4.7
\end{tabular} 
Table 1 - Continuation.

\begin{tabular}{|c|c|c|c|c|c|}
\hline \multirow{2}{*}{ Táxon } & \multicolumn{5}{|c|}{ Sites } \\
\hline & 1 & 2 & 3 & 4 & 5 \\
\hline \multicolumn{6}{|l|}{ Tribe Blepharidattini } \\
\hline Wasmannia auropunctata (Roger, 1863) & & & & & 2.0 \\
\hline \multicolumn{6}{|l|}{ Tribe Cephalotini } \\
\hline Cephalotes pusillus (Klug, 1824) & 1.6 & 2.1 & & & \\
\hline Cephalotes sp. & & 2.1 & & & 2.0 \\
\hline \multicolumn{6}{|l|}{ Tribe Crematogastrini } \\
\hline Crematogaster corticicola (Mayr, 1887) & 3.1 & & 2.3 & & \\
\hline Crematogaster sp. 1 & 1.6 & & & & \\
\hline Crematogaster sp. 3 & & & & 4.8 & \\
\hline
\end{tabular}

Tribe Myrmicini

Pogonomyrmex naegelii Forel, 1879

Pogonomyrmex sp. 1

\begin{tabular}{l|l}
\hline & 4.7 \\
\hline 4.3 &
\end{tabular}

Pogonomyrmex sp. 2

Tribe Pheidolini

Pheidole sp. 1

Pheidole sp. 2

9.4

10.6

9.3

9.5

Pheidole sp. 3

1.6

Pheidole sp. 4

7.8

4.3

Pheidole sp. 5

1.6

Pheidole sp. 6

Tribe Solenopsidini

Solenopsis saevissima (F. Smith, 1855)

\begin{tabular}{|l|l|l|}
\hline & 9.5 \\
\hline 2.3 & 9.5 & 2.0 \\
\hline & & \\
\hline 7.0 & & \\
\hline
\end{tabular}

Solenopsis sp. 1

Solenopsis sp. 2

Solenopsis sp. 3

Monomorium pharaonis (Linnaeus, 1758)

Subfamily Ponerinae

Tribe Ponerini

Hypoponera sp.

Odontomachus chelifer (Latreille, 1802)

Odontomachus sp.

Pachycondyla crenata (Roger, 1858)

Pachycondyla striata F. Smith, 1858

Pachycondyla villosa (Fabricius, 1804)

Pachycondyla sp.

\begin{tabular}{|l|l|l|l|l|}
\hline & 2.1 & & & \\
\hline & & 2.3 & & \\
\hline & 4.8 & 7.0 & & 2.0 \\
\hline 9.4 & 2.1 & 2.3 & 14.3 & 7.8 \\
\hline
\end{tabular}

Subfamily Pseudomyrmecinae

Tribe Pseudomyrmecini

Pseudomyrmex flavidulus (F. Smith, 1858) 
was observed at site $2\left(H^{\prime}=2.86\right)$, whereas the lowest, at site $4\left(H^{\prime}=1.39\right)$. The same pattern was observed for the evenness, with the highest value recorded at site 2 $\left(J^{\prime}=0.89\right)$ and the lowest, at site $4\left(J^{\prime}=0.56\right)$ (Table 2).

The species accumulation curve showed the need for a more intensive sampling effort, because it did not reach the asymptote, both for observed and estimated richness (Chao 1). Except for site 4, where the estimated richness was considerably close to that observed, in the other sites sampled, the species richness recorded was far from the estimated values (Chao 1) (Figure 2).
The first two DCA axes had eigenvalues of 0.49 and 0.42 , respectively (Figure 3 ). In the multivariate diagram, we observed the separation of summer and winter samples regarding the ant community composition in the fragments. The winter sample in site 4 segregated from the others by the lowest richness among all sampling sites and also the exclusive record of Crematogaster sp. 1 and almost exclusive of S. saevissima. However, evaluating the influence of seasons and sites on the ant fauna in the fragments, there was no significant difference in both axes $(p>0.05)$.

Table 2 - Ecological indicators for ant assemblages in samples from five sites under the direct impact from small hydropower plants in the Fortaleza River, municipalities of Piraí do Sul, Tibagi and Ventania, state of Paraná, Brazil. September 2014 and January 2015.

\begin{tabular}{|l|c|c|c|c|c|c|}
\hline Ecological & \multicolumn{5}{|c|}{ Sites } \\
\hline Indicators & 1 & 2 & 3 & 4 & 5 \\
\hline Richness & 24 & 25 & 25 & 11 & 26 \\
\hline Occurrences & 252 & 78 & 123 & 75 & 102 \\
\hline Diversity (H') & 2.35 & 2.86 & 2.60 & 1.39 & 2.16 \\
\hline Equitability $\left(\mathrm{J}^{\prime}\right)$ & 0.74 & 0.89 & 0.81 & 0.58 & 0.66 \\
\hline Chao 1 & 33.3 & 38.7 & 31.4 & 13.0 & 37.4 \\
\hline
\end{tabular}

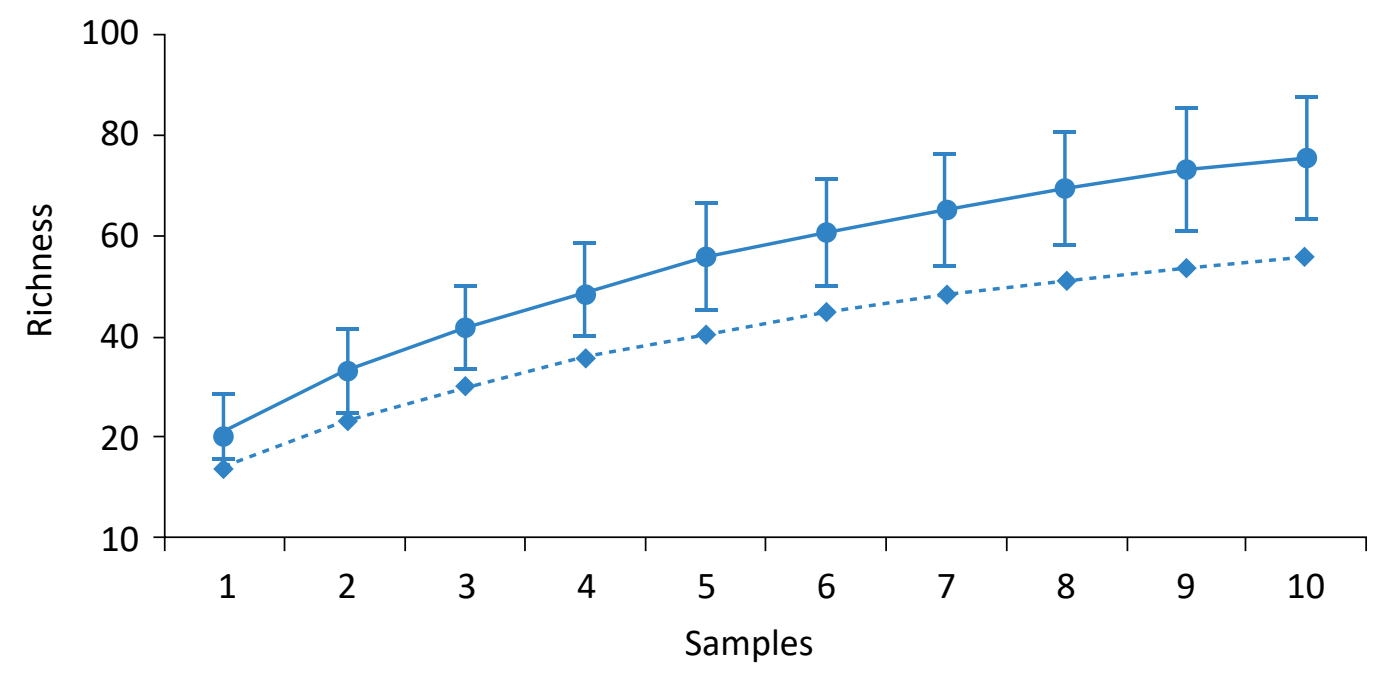

$\rightarrow$ Chao $1 \quad \ldots \rightarrow$ Observed richness

Figure 2-Observed and estimated (Chao 1) richness of ants in samples from five sites under the direct impact from small hydropower plants in the Fortaleza River, municipalities of Piraí do Sul, Tibagi and Ventania, state of Paraná, Brazil. September 2014 and January 2015. 


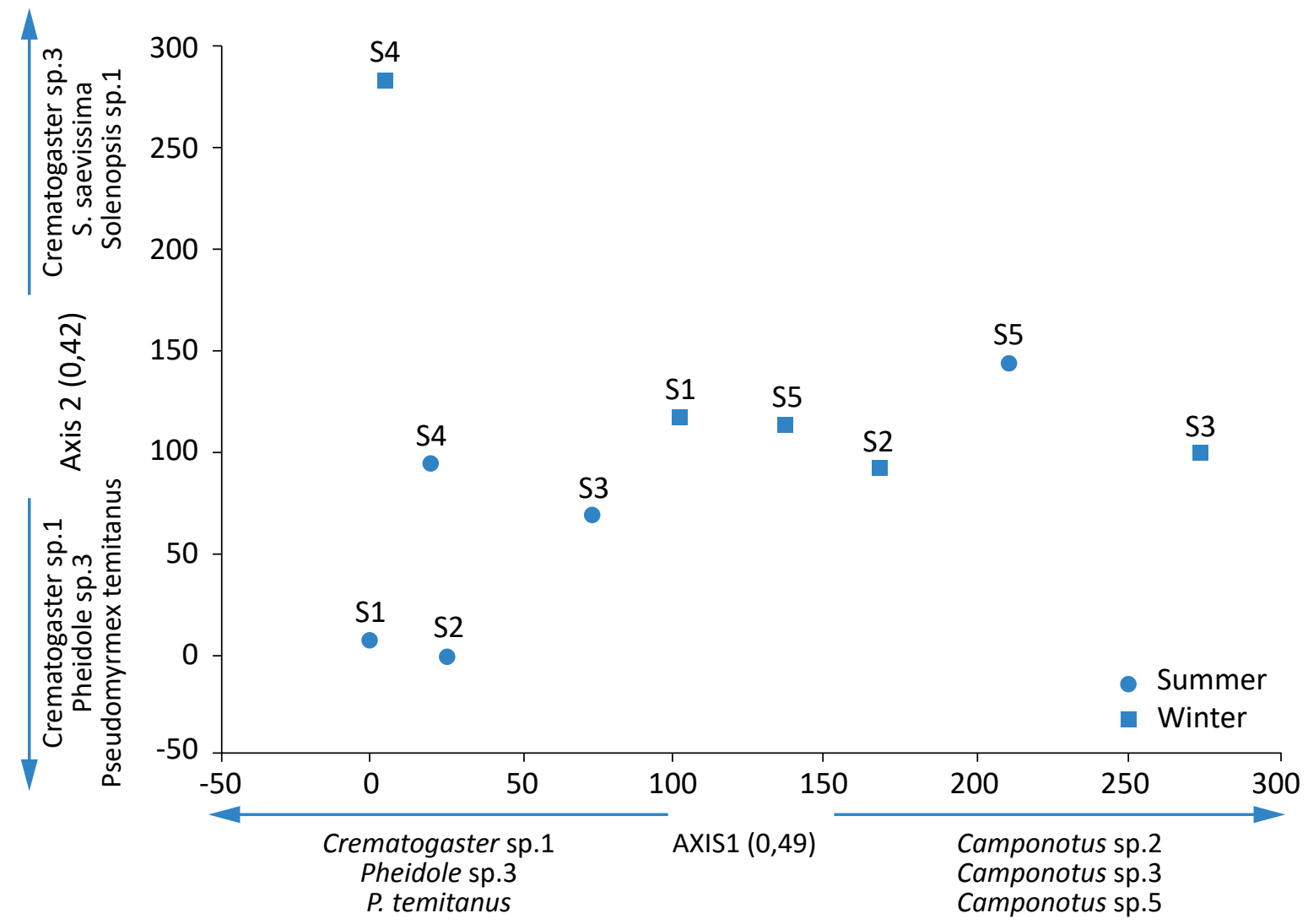

Figure 3 - Ordination of ant fauna composition by detrended correspondence analysis (DCA) in samples from five sites under the direct impact from small hydropower plants in the Fortaleza River, municipalities of Piraí do Sul, Tibagi and Ventania, state of Paraná, Brazil. September 2014 and January 2015.

\section{DISCUSSION}

The richness of ants recorded in this study was below other surveys performed in forested environments in southern Brazil (ULYSSÉA et al., 2011; LUTINSKI et al., 2014), however, is more than double the richness of ants verified by Maciel et al. (2011) in southern state of Paraná. The pattern of species composition was similar to other studies in Brazilian ecosystems with predominance of the subfamily Myrmicinae and the genera Camponotus and Pheidole (ILHA et al.,2009; LUTINSKI et al., 2013a). The fact that only two samplings were conducted may have influenced the richness, as indicated by the Chao1 estimator. The diversity $\left(H^{\prime}\right)$ and evenness ( $\left.J^{\prime}\right)$ represented the characteristics of the sites, since the highest values were obtained in those with the best conditions (plant community at a more ad- vanced stage of succession and better formed litter) for the maintenance of ant fauna. It is noteworthy the difference in composition of ant fauna sampled in the two samplings and homogeneity among the assemblages in the five sites.

The subfamily Myrmecinae is dominant in Brazilian biomes, such as the Atlantic Forest and Cerrado, both in number of genera and species. Some characteristics are remarkable for the success of this subfamily, including the diversity of feeding and nesting habits (HÖLLDOBLER; WILSON, 1990). Additionally, the predominance of Myrmicinae can be because it is extremely adapted to changes in the different environmental conditions and can occupy various niches (GUZMÁN-MENDOZA et al., 2016). 
The sampled sites have characteristics in common, such as the strong anthropic action in adjacent areas, where forest fragments are small and isolated by huge areas of agriculture and livestock. Environments with these characteristics allow species tolerant to alterations in environmental physical conditions, with ability to colonize environments disturbed by human activities, such as some species of Camponotus, Crematogaster, Linepithema, Pheidole and Solenopsis, to settle and become abundant and dominant in these environments (LUTINSKI et al., 2013a).

It is important to emphasize the diversity of Pachycondyla and Pseudomyrmex in the samples, once these ants are associated with litter and vegetation, respectively, where they nest and find prey (BACCARO et al., 2015). The pseudomyrmecinae ants are agile and solitary patrol with well-developed vision and diurnal habits. Among the 180 species described for the Neotropics, most are associated with vegetation. Many of them are dependent on myrmecophilous plants (BACCARO et al., 2015). They visit nectaries and some predate on the ground. They prefer dense and humid forests although some can be found in open areas (WARD, 2003). The association of entomofauna with remnant forest fragments may also explain the occurrence of Cephalotes ants, whose species need shelter and nesting place in the vegetation. Cephalotes ants are essentially arboreal and rarely come down to the ground. They are associated with vegetation where they find a source of supply and place to build their nests, so they are very dependent on good local flora conditions in order to establish (FERNÁNDEZ, 2003).

The species richness and composition proved to be influenced by the habitat structure, mainly the site 4 , which is an intermediate recovery area with little litter and no capacity to support a more diverse ant fauna, corroborating Arenas et al. (2015), who stated that simplified environments usually contain a lower richness and diversity of ants, with a fauna made up of generalist species. The other sites showed a more similar richness and composition, and probably have sufficient structural heterogeneity to allow a smaller niche overlap and therefore increase the number of ant species in these areas. According to Queiroz and Ribas (2016), the environmental heterogeneity is a determining factor for the coexistence of species and re- duction in competition. Other factors that can act for the determination of this pattern are the size of the fragments and the conservation status. The occurrence of Gnamptogenys and Hypoponera is an important indicator of environmental conservation, because, in agreement with Valdés-Rodríguez et al. (2014), ants of these genera share, beyond the predatory habit, the habit of building nests in fallen logs, under rocks or on the litter, in general, that is, require environments with structure capable of sheltering these species.

The seasonal effect on the richness and composition of the ant community was remarkable, since species richness was higher in the winter. The temperature is limiting to the metabolism of insects in general, which are more active in periods of the year with higher temperatures (HÖLLDOBLER; WILSON, 1990). Nevertheless, in this study, this hypothesis was not confirmed, which can be attributed to rainfall registered in the field ( $100 \mathrm{~mm}$ ) during the sampling in January 2015 (summer).

The diversity index indicates that ant assemblages in the ADI are poor, equivalent to the insect fauna found in monoculture areas of the region, such as plantations of pine and eucalyptus, and is lower than that found in preserved areas (COSTA-MILANEZ et al., 2014). The highest values of Shannon found in site 2 are closely related to the preservation of the forest fragment. According to Peralta and Martínez (2013), evenness index ranges from zero to one, and a result greater than 0.5 indicates uniformity in the distribution of species in the evaluated location. The low frequency of most of the species of ants in the samples explains the high evenness of the assemblages, in each of the sites. As observed in this study, the presence of many uncommon species is a pattern well-documented for tropical and neotropical regions (CHACÓN DE ULLOA; ABADÍA, 2014).

In relation to sampling effort, the results indicate that the richness of ants of the AID may be higher than observed in the samples. The species accumulation curves of the five sites studied presented an upward trend at the end of the samplings. Given the diverse biological and ecological characteristics of ants (HÖLLDOBLER; WILSON, 1990), the sampling techniques used and the two samplings performed, the results allow us to infer sampling sufficiency. However, for the accumulation curves to reach a perfect asymptote, additional samples are required, using complementary techniques and for a longer period, to properly survey the diversity. 
Although the DCA axes were not significant, there is a trend of seasonal influence on the species composition. The ant species evaluated may have different responses to variations in temperature and rainfall, typical of winter and summer seasons. These variations can affect nesting and foraging activity of ants (GALLEGO-ROPERO; RIVERA, 2015). Possibly, ants regulate the foraging activity based on these climate characteristics, thus explaining the difference in the composition between the seasons. Moreover, there are other variables related to the complexity of the environment, such as the presence of understory and litter, which can play a decisive role in structuring the ant community in the area under the impact from SHP.
The presence of ants indicates the existence of a complex fauna of prey and other organisms, in this way, the invertebrate richness of the AID can be considered significant, though poor when compared with preserved environments. This fauna keeps colonizing and using forest remnants in the AID as a refuge. The removal of vegetation and formation of lakes in the DAA, from the implementation of three SHP, may cause microclimate changes in the AID, which may impact the richness, abundance and composition of ant assemblages colonizing the forest remnants of the Fortaleza River basin. These impacts can be monitored based on the results of this study.

\section{REFERENCES}

ALONSO, L.E.; AGOSTI, D. Biodiversity studies, monitoring, and ants: an overview.In: AGOSTI, D.; MAJER, J.D.; ALONSO; L.E.; SCHULTZ, T.R. (Orgs.). Ants: standard methods for measuring and monitoring biodiversity. Washington: Smithsonian Institution. 2000. p. 1-8.

ARENAS, A.; CORREDOR, G.; ARMBRECHT, I. Hormigas y carábidos en cuatro ambientes del piedemonte del Parque Nacional Natural Farallones de Cali, Colombia. Revista Colombiana de Entomología, v. 41, n. 1, p. 120-125, 2015.

BACCARO, F.B.; FEITOSA, R.M.; FERNANDEZ, F.; FERNANDES, I.O.; IZZO, T.J.; SOUZA, J.L.P. de; SOLAR, R. Guia para os gêneros de formigas do Brasil. Manaus: Editora Inpa, 2015. 388 p.

BARBOSA-FILHO, W.P. Impactos ambientais em usinas eólicas. In: CONGRESSO SOBRE GERAÇÃO DISTRIBUÍDA E ENERGIA NO MEIO RURAL, 2013. Anais...Belo Horizonte: Fundação Estadual do Meio Ambiente,2013. p.1-17.

BOLTON, B. Synopsis and classification of Formicidae. Gainesville: The American Entomological Institute, 2003. 370 p.

CHAO, A. Estimating the population size for capture-recapture data with unequal catch ability. Biometrics, v. 43, n. 4, p. 783-791, 1987.

CHACÓN DE ULLOA, P.; ABADÍA, J.C. Dos décadas de estudio de la diversidad de hormigas en Colombia. Revista de la Academia Colombiana de Ciencias Exactas, Físicas y Naturales, v. 38, n. 148, p. 250-260, 2014.

COLWELL, R.K. EstimateS: Statistical Estimation of Species Richness and Shared Species from Simples (Software and User's Guide), Versão 8.2006. Available from: <http://viceroy.eeb.uconn.edu/estimates/>. Access on: 30 Oct. 2015.

COSTA-MILANEZ, C.B.; LOURENÇO-SILVA, G.; CASTRO, P.T.A.; MAJER, J.D.; RIBEIRO, S.P. Are ant assemblages of Brazilian veredas characterised by location or habitat type? Brazilian Journal of Biology, v. 74, n. 1, p. 89-99, 2014.

DIAMOND, J.Colapso. 8.ed. Rio de Janeiro: Record, 2012.699 p.

FERNÁNDEZ, F. Introducción a las hormigas de la región neotropical. Bogotá: Instituto de Investigación de Recursos Biológicos Alexander von Humboldt,2003. 426 p.

GALINDO-LEAL, C.; CÂMARA, I.G. The Atlantic Forest of South America:Biodiversity status, threats, and outlook. Washington, D.C.: Island Press,2003. 488 p.

GALLEGO-ROPERO, M.C.; RIVERA, B.S. Ensamblaje de hormigas del bosque seco tropical, Jardín Botánico de Cali. Colombia Forestal, v. 18, n. 1, p. 139-150, 2015. 
GONÇALVES, R.B.;MELO, G.A.R. A comunidade de abelhas (Hymenoptera,Apidae) em uma área restrita de campo natural no Parque Estadual de Vila Velha,Paraná: Diversidade, fenologia e fontes florais de alimento. Revista Brasileira de Entomologia, v. 49, p. 557-571, 2005.

GUZMÁN-MENDOZA, R.; CASTAÑO-MENESES, G.; NUÑEZ-PALENIUS, H.G. The diversity of ant communities (Hymenoptera: Formicidae) and their connections with other arthropods from three temperate forests of Central Mexico. Revista de Biología Tropical, v. 64, n. 2, p. 571-585, 2016.

HAMMER, O.; HARPER, D.A.T.; RYAN, P.D. Past: Palaeonthological statistics software package for education and data analysis. Version. 1.37. 2001. Available from: <http://palaeo-electronica.org/2001_1/past/issue1_01.htm>. Access on: 23 mar. 2016.

HÖLLDOBLER, B.; WILSON, E.O. The ants. Cambridge: Harvard University Press, 1990. 732 p.

ILHA, C.; LUTINSKI, J.A.; PEREIRA, D.V.M.;GARCIA, F.R.M. Riqueza de formigas (Hymenoptera: Formicidae) da Bacia da Sanga Caramuru, município de Chapecó-SC. Biotemas, v. 22, n. 4, p. 95-105, 2009.

JAMISON, S.L.; ROBERTSON, M.; ENGELBRECHT, I.; HAWKES, P. An assessment of rehabilitation success in an African grassland using ants as bioindicators. Koedoe, v. 58. n. 1, p. 1-16, 2016.

KLIEMANN, B.C.K.;DELARIVA, R.L.Pequenas centrais hidrelétricas: cenários e perspectivas no estado do Paraná. Ciência e Natura,v. 37, n. 3, p. 274-283, 2015.

LUTINSKI, J.A.; BAUCKE, L.; FILTRO, M.; BUSATO, M.A.; KNAKIEWICZ, A.C.; GARCIA, F.R.M. Ant assemblage (Hymenoptera: Formicidae) in three wind farms in the State of Paraná, Brazil. Brazilian Journal of Biology, v. 77, n. 1, p. 176-184, 2017.

LUTINSKI, J.A.; LOPES, B.C.; MORAIS, A.B.B. Diversidade de formigas urbanas (Hymenoptera: Formicidae) de dez cidades do sul do Brasil. Biota Neotropica, v. 13, n. 3, p. 332-342, 2013 a.

LUTINSKI, J.A.; LUTINSKI, C.J.; IOP, S.;GARCIA, F.R.M.Evaluation of an ant sampling protocol (Hymenoptera: Formicidae) in three modified environments located inside an austral Atlantic Forest area of Brazil. Ecología Austral,v. 23, p. 37-43, 2013b.

LUTINSKI, J.A.; LUTINSKI, C.J.; LOPES, C.B.; MORAIS, A.B.B. Estrutura da comunidade de formigas (Hymenoptera: Formicidae) em quatro ambientes com diferentes níveis de perturbação antrópica. Ecología Austral, v. 24, n. 2, p. 229 237, 2014.

MACIEL, L.; IANTAS, J.; GRUCHOWSKI-W, F.C.;HOLDEFER, D.R. Inventário da fauna de formigas (Hymenoptera: Formicidae) em ambiente de sucessão ecológica florística no município de União da Vitória, Paraná. Biodiversida Pampeana,v. 9, n. 1, p. 38-43, 2011.

MAGURRAN, A.E. Ecological diversity and its measurement. New Jersey:Princeton University Press,1988. 179 p.

PERALTA, L.; MARTínEZ, P.A. Ensambles de ácaros oribátidos en hormigueros de Acromyrmex spp. (Hymenoptera, Formicidae). Ecología Austral, v. 23, n. 3, p. 209-217, 2013.

QUEIROZ, A.C.M.; RIBAS, C.R. Canopy cover negatively affects arboreal ant species richness in a tropical open habitat. Brazilian Journal of Biology, v. 76, n. 4, p. 864-870, 2016.

SAKAGAMI, S.F.; LAROCA, S.;MOURE, J.S. Wild bee biocenotics in São José dos Pinhais (PR), South Brazil. Preliminary Report. Journal of the Faculty of Science, v. 16, p. 253-291, 1967.

STATSOFT, Inc. STATISTICA (data analysis software system), version 8.0. 2007. Available from: <http://www.statsoft. com>.Access: 20 jul. 2011. 
ULYSSÉA, M.A.;CERETO, C.E.;ROSUMEK, F.B.;SILVA, R.R.;LOPES, B.C. Updated list of ant species (Hymenoptera, Formicidae) recorded in Santa Catarina State, southern Brazil, with a discussion of research advances and priorities. Revista Brasileira de Entomologia,v. 55, n. 4, p. 603-611, 2011.

VALDÉS-RODRÍGUEZ, S.; CHACÓN DE ULLOA, P.; ARMBRECHT, I. Especies de hormigas del suelo en el Parque Nacional Natural Gorgona, Pacífico Colombiano. Revista de Biología Tropical, v. 62, Suppl. 1, p. 265-276, 2014.

WARD, P.S. Subfamília Pseudomyrmecinae. In: FERNÁNDEZ, F. (Ed.). Introducción a las hormigas de la región neotropical. Bogotá, Colombia:Instituto de Investigación de Recursos Biológicos Alexander von Humboldt,2003. p. 331-333. 